\title{
Habitat and weather conditions effects on long-term breeding population dynamics of five species of herons (Ardeidae) and Glossy ibis (Threskiornithidae) in the Valencian Community, Spain
}

\author{
Mariela Forti ${ }^{1, *}$, Juan S. Monrós $^{1}$ (D) and Pablo Vera ${ }^{2}$ \\ ${ }^{1}$ Institut "Cavanilles" de Biodiversitat i Biologia Evolutiva. Universitat de València. C/ Catedrático José Beltrán \\ $\mathrm{n}^{\circ}$ 2. 46980 Paterna - Valencia. Spain. \\ 2 SEO/BirdLife. C/ Tavernes Blanques, 29 - 46120 Alboraya, Valencia. Spain. \\ * Corresponding author: mfpronti@gmail.com
}

Received: $10 / 07 / 20 \quad$ Accepted: $15 / 10 / 20$

\begin{abstract}
Habitat and weather conditions effects on long-term breeding population dynamics of five species of herons (Ardeidae) and Glossy ibis (Threskiornithidae) in the Valencian Community, Spain

Valencian wetlands include $65 \%$ of the region's priority habitats and most are protected areas. Waterfowl populations are used as indicators of the state of these environments. We calculated the linear population trend by species, per wetland, of five Ardeidae and Plegadis falcinellus (Threskiornitidae) species using data from the annual census between 1984-2015 for 11 selected wetlands. We constructed a matrix with 42 habitat and meteorological variables, and evaluated the relation between these variables and population trends by a Correspondence Analysis. We found an increasing trend for most species. The populations of the L'Albufera de Vàlencia Natural Park (NP) differed significantly from the rest. Ardea cinerea, E. garzetta, B. ibis and A. ralloides would be associated with large areas, and also with swamps and rice fields, while A. purpurea and $P$. falcinellus would be related to environments characterised by rainfall and the level of protection in the area. Rice fields and water management have been important for establishing breeding colonies.
\end{abstract}

Key words: population trends, breeding populations, Ardeidae, Mediterranean wetlands, protected areas, water birds counts, rice fields, heron populations

\section{RESUMEN}

Efectos del hábitat y las condiciones meteorológicas en la dinámica poblacional a largo plazo de cinco especies de garzas (Ardeidae) y el morito común (Threskiornithidae) en la región de Valencia, España

Los humedales valencianos incluyen el $65 \%$ de los hábitats prioritarios de la región y la mayoría son áreas protegidas. Las poblaciones de aves acuáticas se utilizan como indicadores del estado de estos ambientes. Calculamos la tendencia poblacional lineal por especie, por humedal, de cinco especies de Ardeidae y de Plegadis falcinellus (Threskiornitidae), utilizando datos del censo anual entre 1984-2015, para 11 humedales seleccionados. Además, construimos una matriz con 42 variables de hábitat y meteorológicas y evaluamos la relación entre estas variables y las tendencias poblacionales mediante un Análisis de Correspondencia. Encontramos una tendencia creciente para la mayoria de las especies. Las poblaciones del PN L'Albufera de Vàlencia difieren significativamente del resto. Ardea cinerea, E. garzetta, B. ibis y A. ralloides estarían asociadas con áreas grandes y con pantanos y arrozales, mientras que A. purpurea $y \mathrm{P}$. falcinellus estarían relacionados con ambientes caracterizados por las precipitaciones y el nivel de protección del área. Los campos de arroz y la gestión del agua han sido importantes en el establecimiento de colonias de cría.

Palabras clave: tendencias poblacionales, poblaciones reproductivas, Ardeidae, humedales mediterráneos, áreas protegidas, conteos de aves acuáticas, arrozales, poblaciones de garzas 


\section{INTRODUCTION}

Wetland ecosystems, which provide the population with lots of economic and intangible services, are the most threatened on the planet (Millenium Ecosystem Assessment, 2005; MedWet, 2016). Therefore, initiatives for their conservation are of vital importance (Millenium Ecosystem Assessment, 2005). Water bird trends are considered good indicators of wetlands status (Green \& Figuerola, 2003; Gómez-López et al., 2006; Palomino \& Molina, 2009). Nevertheless, their effective efficiency depends partly on their scale (Green \& Figuerola, 2003). On lower scales, the physical characteristics of wetlands, such as size, form, presence and distribution of emergent vegetation or proximity to other wetlands, influence water bird diversity and abundance (Craig \& Beal, 1992; Green \& Figuerola, 2003). On a larger scale, landscape heterogeneity is closely related to species richness (Atauri \& de Lucio, 2001).

On the Mediterranean coast of the Iberian Peninsula, many lagoons and marshes represent most of the total area of wetlands in this region. Wetlands in the Valencian Community, located east of the Iberian Peninsula, harbour $65 \%$ of the existing priority habitats and provide shelter for $50 \%$ of the rare, endemic and threatened species of their biota (Ferrer-Polo et al., 2006). These figures place these wetlands among the most valuable in the peninsula (Gómez-López et al., 2006), and most are included in the Natura2000 Network (Red Natura, 2000) or the RAMSAR Convention. The majority of these environments are important breeding and wintering sites for waterfowl. The most important for both species richness and abundance are the wetlands of Prat de Cabanes-Torreblanca, L'Albufera de València, Marjal de Pego-Oliva, Salinas de Santa Pola, Lagunas de La Mata-Torrevieja and El Hondo (Martínez-Abrain et al., 2016). Considering only the group of herons, the wetlands in the Valencian Community harbour $9.3 \%$ of the winter population and $11.1 \%$ of the breeding population in Spain, and respectively occupy fourth and fifth place nationally (Garrido et al., 2012). L'Albufera de València is specifically the third most important site for heron reproduction in Spain (Garrido et al., 2012).

The heron species evaluated in this study are Egretta garzetta (Little Egret), Bubulcus ibis (Cattle Egret), Ardeola ralloides (Squacco Heron), Ardea cinerea (Grey Heron), Ardea purpurea (Purple Heron), and one Threskiornitidae, Plegadis falcinellus (Glossy Ibis). Most of these species appear in some national or international protection or conservation category. Internationally, these species are classified as Least Concern on the IUCN Red List (BirdLife International, 2016), and the Purple Heron and the Glossy Ibis are included in Appendix II of the Bonn Convention (Council Decision 82/461/ EEC). Therefore, they are subject to regulations and international cooperation to keep their populations safe. Moreover, in the Birds Directive (Directive 2009/147/EC), five of the studied species, except the Cattle Egret and the Grey Heron, are listed as threatened, vulnerable, rare or require special attention (Appendix I). In the Red Book of the Birds of Spain (Madroño et al., 2004), the Squacco Heron is listed as Near Threatened and the Glossy Ibis as Vulnerable according to IUCN criteria. However, 16 years have passed since the last edition of the Red Book of the Birds of Spain, during which time the populations of some species may present changes; e.g., the Glossy Ibis, whose breeding and wintering populations have remarkably increased (Santoro et al., 2013, 2016) which will probably change its conservation status in the next edition. The Squacco Heron is listed as Endangered on the National List of Endangered Species (Real Decreto 139/2011) and in the Valencia Catalogue of Endangered Fauna Species (Decreto 32/2004). On the same list, the Purple Heron is catalogued as Vulnerable. However, the overall breeding population of herons has increased from just over 2500 pairs (in the 1980s) to about 7000 in 2013 (Generalitat Valenciana, 2013), although their numbers have recently diminished by $43 \%$ (Generalitat Valenciana, 2016). Some of these species found in any protection category have significantly increased in the last few decades in Spain, such as Grey Heron, Purple Heron, Squacco Heron and Glossy Ibis (Pérez-Aranda et al., 2003; Figuerola et al., 2003; Garrido et al., 2012; Ramo et al., 2013), and even these last two have 
reached historic highs in the Valencian Community in 2015 and 2016 (Generalitat Valenciana, 2015; 2016). This increase has been considered a direct consequence of the environmental protection policies carried out in the wetlands of this region in the same time period (Martínez-Abrain et al., 2016).

Our objectives were to evaluate the trends of the breeding populations of the study species in Valencian Community wetlands, and to elucidate which characteristics of this habitat, along with some weather conditions (i.e. temperature and rainfall), contribute or determine the size of these

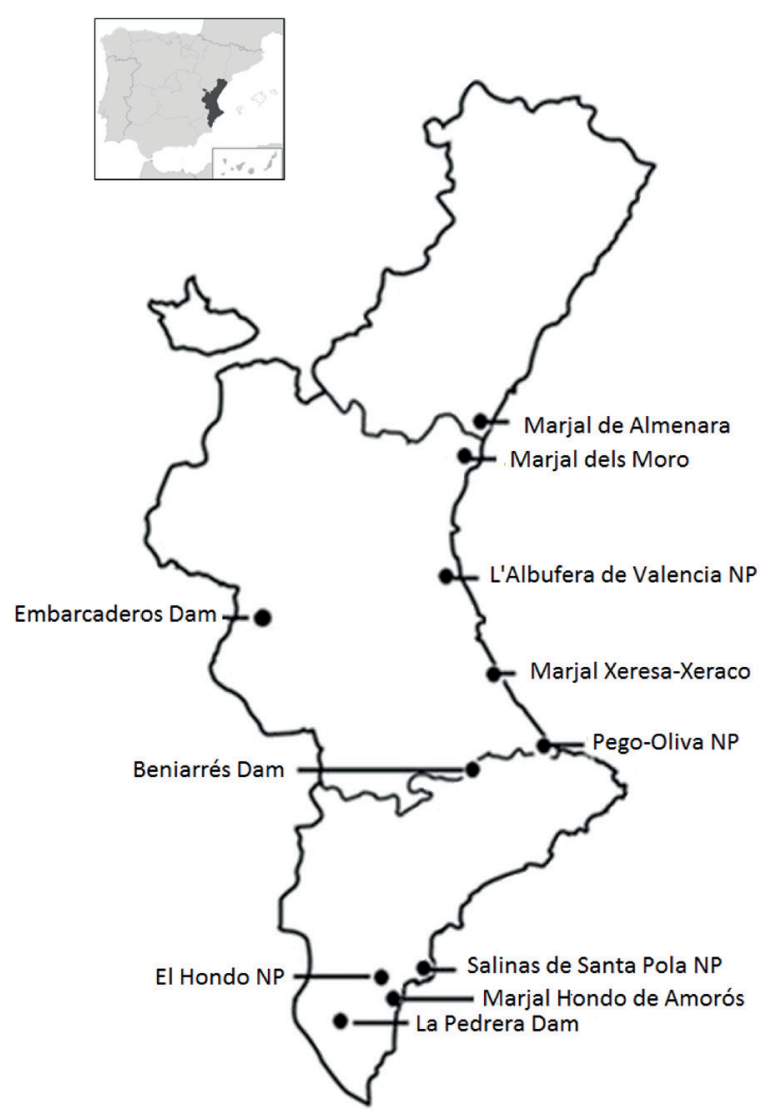

Figure 1. Location of the study wetlands to the east of the Iberian Peninsula. Ubicación de los humedales estudiados en el este de la península ibérica. (Marjal de Almenara: MA, Marjal dels Moro: MM, Marjal Xeresa-Xeraco: MXX, Marjal Hondo de Amorós: MHA, L'Abufera de Valencia NP: LANP, Pego-Oliva NP: PONP, Salinas de Santa Pola NP: SPNP, El Hondo NP: EHNP, La Pedrera Dam: ELP, Beniarrés Dam: EB, Embarcaderos Dam: EE) species' reproductive colonies. This information will help to manage both the species and habitats they occupy, which are mostly protected areas.

\section{METHODS}

\section{Study area}

The Valencian Community is located to the east of the Iberian Peninsula (Fig. 1). Thirteen of the 48 sites on the List of Wetlands in this region (Generalitat Valenciana, 2002a) are SPAs (Birds Directive, 2009/147 / CE) included in the Natura 2000 Network. Marshes, lagoons and deltas are the environments with the largest heron colonies, where they nest mostly in marsh vegetation like reeds (Phragmites sp.) and bulrushes (Typha sp.), and represent $43 \%$ of total breeding populations of these species in this region (Garrido et al., 2012). The habitat surrounding these sites consists of either meadows and grasslands or agricultural areas, and extensive rice fields that are key for the foraging of herons and the Glossy Ibis (Hafner et al., 1987, Fasola \& Ruiz, 1996, Garrido et al., 2012).

Of the 48 wetlands defined by the List of Wetlands in the Valencian Community, we selected 11 with active breeding for at least 3 consecutive years (during the 1984-2015 period) and with a minimum of 10 pairs (Fig. 1). These wetlands are L'Albufera de Vàlencia Natural Park (LANP), Salinas de Santa Pola Natural Park (SPNP), El Hondo Natural Park (EHNP), Pego-Oliva Natural Park (PONP), Marjal de Almenara (MA), Marjal dels Moros (MM), Marjal de Xeresa-Xeraco (MXX), Marjal Hondo de Amorós (MHA), Beniarrés Dam (EB), La Pedrera Dam (ELP) and Embarcaderos Dam (EE). Currently, $97 \%$ of the entire breeding population of the Valencian Community nests in these localities (Generalitat Valenciana, 2015; 2018).

\section{Population trends}

Since 1984, SEO/BirdLife and the Conselleria de Medio Ambiente of the regional government have periodically conducted annual censuses using the same sampling technique. They derive the number of pairs from the number of 
nests or adults incubating, except in areas with difficult access, where they were estimated from the number of adult reproducers present (Goméz-Lopéz et al., 2006). In this study, we used the number of nesting pairs in the Valencian Community for the 32 years of consecutive censuses (1984-2015) and six species in all: Grey Heron, Purple Heron, Squacco Heron, Cattle Egret, Little Egret (Ardeidae), Glossy Ibis (Threskiornithidae).

The linear trend was calculated per species in each wetland and in the whole of the Valencian Community to observe breeding population trends in the long (32 years of censuses), mid (last 16 years) and short (last 8 years) terms. An autocorrelation analysis was performed on the number of breeding pairs per species in each wetland to verify that there was no spurious relation between population size and time (Santoro et al., 2010). If data were autocorrelated, we assumed that there was no population trend, unless the significance value of the linear trend was $p<0.01$ (Hatfield et al., 1996; Santoro et al., 2010).

To evaluate whether there was a preference shown by some species for certain wetlands, and if it was significantly more abundant in some than in others, the non-parametric Kruskal-Wallis test was performed (only the data from two localities were normally-distributed). In this way it was possible to identify which wetlands would be the most important for the conservation of each particular species. The Mann-Whitney post hoc test was used and box plots were generated. To determine if the populations of a given species covaried between different wetlands, the population sizes of each species in each wetland were analysed by a Spearman correlation with Bonferonni correction. We ran the analyses with version 3.14 of the Past3 programme (Hammer et al., 2001).

How species composition changed with time and the order of colonisation in the most important wetlands were also evaluated by taking the number of pairs per species in each one at three different times during the census period: at the beginning (1984 for the LANP, 1985 for EHNP and 1988 for the rest), halfway (2000) and for the last census (2015).

\section{Habitat variables}

We created a matrix with 42 habitat variables that could be related to the population trends in each wetland (Table 1). As freshwater wetlands and marshes are positively related to heron colonies (Hafner et al., 1987), the area of the marsh or flooded area (with or without vegetation) was included as a variable. This variable and the total area of the protected wetlands were obtained using GoogleEarth ${ }^{\circledR}$ (images from 2016), as was the distance from the wetland to the most important protected areas (L'Albufera de València and El Hondo). These wetlands house the largest heron populations (Garrido et al., 2012; Generalitat Valenciana 2015; 2018) and trends in these large populations can influence the population trends in the closest wetlands. Likewise, we considered the average monthly temperatures during reproduction (March-July), and also the total rainfall during the non-breeding season (September-April) because it may affect success in the following breeding season (Hafner et al., 1994; Lekuona, 2002). We obtained these weather data from the AEMET (Meteorology Statal Agency) database, available either on the web (AEMET OpenData) or provided by the agency. The conservation category and protection time of each locality were also considered as environmental protection policies and the protection status of colonies have an effect on population trends (Fasola et al., 2010; Martínez-Abrain et al., 2016). We also took into account the proportions of land use within radii of 5,10 and $15 \mathrm{~km}$ around nesting colonies, calculated with GVSig (version 2.2.0.2313) from data on the latest available CorineLandCover map (2012). They were chosen because the type habitat surrounding breeding colonies influences their size and population trend, as well as the reproductive and feeding success of herons (Hafner et al., 1987, Fasola et al., 2010, Manikowska-Slepwronska et al., 2016). Distances were selected by bearing in mind that herons feed mostly within a radius of between 5 and $10 \mathrm{~km}$, but some species can move away as far as $15 \mathrm{~km}$ from the colony (Hafner et al., 1987; Manikowska-Slepwronska et al., 2019). We were unable to determine the variation in the area occupied by each land use type for the 
Table 1. Variables considered in the Correspondence Analysis between the population sizes of heron species and the habitat characteristics of the different wetlands. Variables consideradas en el Análisis de Correspondencia entre los tamaños poblacionales de las especies de garzas y las características de hábitat de los diferentes humedales.

\begin{tabular}{|c|c|c|}
\hline Variable & Description & Abbreviation \\
\hline Wetland/year & Location/year of census & Ejem: MA88 \\
\hline Total area & Total area of the protected area in hectares & TotalArea \\
\hline Area of marsh & $\begin{array}{l}\text { Surface area in hectares occupied by the water body, } \\
\text { including lake vegetation }\end{array}$ & MarshesArea \\
\hline Distance to L'Albufera NP & $\begin{array}{l}\text { Distance in kilometres from the location in question to the } \\
\text { L'Albufera de Vàlencia Natural Park }\end{array}$ & Dist.PNLA \\
\hline Distance to El Hondo NP & $\begin{array}{l}\text { Distance in kilometres from the location in question to the } \\
\text { El Hondo Natural Park }\end{array}$ & Dist. PNEH \\
\hline Precipitation & $\begin{array}{l}\text { Accumulated rainfall between September and April each } \\
\text { year, prior to the reproductive period }\end{array}$ & PPm \\
\hline Average temperature & $\begin{array}{l}\text { Average temperature between March and July each year } \\
\text { (reproductive period) }\end{array}$ & Temp \\
\hline Category & $\begin{array}{l}\text { The locality's protection category (SPA birds, SCI, Natural } \\
\text { Park, none) }\end{array}$ & Category \\
\hline Protection & Years of protection & Protection \\
\hline $\begin{array}{l}\text { Percentage of water in } 5,10 \text { and } \\
15 \mathrm{~km}\end{array}$ & $\begin{array}{l}\text { Percentage of surface area covered by water (rivers, } \\
\text { lagoons, estuaries, sea) within the radii of 5,10 and } 15 \mathrm{~km} \\
\text { around the colony }\end{array}$ & $\begin{array}{l}\text { Water } 5 \mathrm{Km} \\
\text { Water } 10 \mathrm{Km} \\
\text { Water } 15 \mathrm{Km} \\
\end{array}$ \\
\hline $\begin{array}{l}\text { Percentage of marshes in } 5,10 \\
\text { and } 15 \mathrm{~km}\end{array}$ & $\begin{array}{l}\text { Percentage of surface area covered by marshes within the } \\
\text { radii of } 5,10 \text { and } 15 \mathrm{~km} \text { around the colony }\end{array}$ & $\begin{array}{l}\text { Marshes } 5 \mathrm{Km} \\
\text { Marshes } 10 \mathrm{Km} \\
\text { Marshes } 15 \mathrm{Km}\end{array}$ \\
\hline $\begin{array}{l}\text { Percentage of salt flats in } 5,10 \\
\text { and } 15 \mathrm{~km}\end{array}$ & $\begin{array}{l}\text { Percentage of surface area covered by salt flats within the } \\
\text { radii of } 5,10 \text { and } 15 \mathrm{~km} \text { around the colony }\end{array}$ & $\begin{array}{l}\text { Sal5Km } \\
\text { Sal10Km } \\
\text { Sal15Km }\end{array}$ \\
\hline $\begin{array}{l}\text { Percentage of rice fields in } 5 \text {, } \\
10 \text { and } 15 \mathrm{~km}\end{array}$ & $\begin{array}{l}\text { Percentage of surface area covered by rice fields within the } \\
\text { radii of } 5,10 \text { and } 15 \mathrm{~km} \text { around the colony }\end{array}$ & $\begin{array}{l}\text { Rice } 5 \mathrm{Km} \\
\text { Rice } 10 \mathrm{Km} \\
\text { Rice } 15 \mathrm{Km} \\
\end{array}$ \\
\hline $\begin{array}{l}\text { Percentage of other crops in } 5 \text {, } \\
10 \text { and } 15 \mathrm{~km}\end{array}$ & $\begin{array}{l}\text { Percentage of surface area covered by different crop types } \\
\text { (permanent irrigation, fruit trees, olive trees, mixed) within } \\
\text { the radii of } 5,10 \text { and } 15 \mathrm{~km} \text { around the colony }\end{array}$ & $\begin{array}{l}\text { OtherCrops } 5 \mathrm{Km} \\
\text { OtherCrops } 10 \mathrm{Km} \\
\text { OtherCrops } 15 \mathrm{Km}\end{array}$ \\
\hline $\begin{array}{l}\text { Percentage of forest in } 5,10 \\
\text { and } 15 \mathrm{~km}\end{array}$ & $\begin{array}{l}\text { Percentage of surface area covered by forest type } \\
\text { vegetation (coniferous, broadleaf, mixed) within the radii } \\
\text { of } 5,10 \text { and } 15 \mathrm{~km} \text { around the colony }\end{array}$ & $\begin{array}{l}\text { Forest } 5 \mathrm{Km} \\
\text { Forest } 10 \mathrm{Km} \\
\text { Forest } 15 \mathrm{Km} \\
\end{array}$ \\
\hline $\begin{array}{l}\text { Percentage of other vegetation } \\
\text { in } 5,10 \text { and } 15 \mathrm{~km}\end{array}$ & $\begin{array}{l}\text { Percentage of surface area covered by low vegetation } \\
\text { (bushes, pastures) within the radii of } 5,10 \text { and } 15 \mathrm{~km} \\
\text { around the colony }\end{array}$ & $\begin{array}{l}\text { OtherVeg } 5 \mathrm{Km} \\
\text { OtherVeg } 10 \mathrm{Km} \\
\text { OtherVeg } 15 \mathrm{Km} \\
\end{array}$ \\
\hline $\begin{array}{l}\text { Percentage of } \\
\text { urbanism/industry in } 5,10 \text { and } \\
15 \mathrm{~km}\end{array}$ & $\begin{array}{l}\text { Percentage of surface area covered by buildings (urbanism, } \\
\text { industrial and commercial areas) within the radii of } 5,10 \\
\text { and } 15 \mathrm{~km} \text { around the colony }\end{array}$ & $\begin{array}{l}\text { Urb5Km } \\
\text { Urb10Km } \\
\text { Urb15Km }\end{array}$ \\
\hline $\begin{array}{l}\text { Percentage of beaches in } 5,10 \\
\text { and } 15 \mathrm{~km}\end{array}$ & $\begin{array}{l}\text { Percentage of surface area covered by beaches and dunes } \\
\text { within the radii of } 5,10 \text { and } 15 \mathrm{~km} \text { around the colony }\end{array}$ & $\begin{array}{l}\text { Beach5Km } \\
\text { Beach10Km } \\
\text { Beach15Km }\end{array}$ \\
\hline Grey Heron population size & $\begin{array}{l}\text { Number of breeding pairs of Grey Heron (A. cinerea) for } \\
\text { each census year }\end{array}$ & TpAc \\
\hline Purple Heron population size & $\begin{array}{l}\text { Number of breeding pairs of Purple Heron (A. purpurea) } \\
\text { for each census year }\end{array}$ & TpAp \\
\hline Squacco Heron population size & $\begin{array}{l}\text { Number of breeding pairs of Squacco Heron (A. ralloides) } \\
\text { for each census year }\end{array}$ & TpAr \\
\hline Cattle Egret population size & $\begin{array}{l}\text { Number of breeding pairs of Cattle Egret (B. ibis) for each } \\
\text { census year }\end{array}$ & $\mathrm{TpBi}$ \\
\hline Little Egret population size & $\begin{array}{l}\text { Number of breeding pairs of Little Egret (E. garzetta) for } \\
\text { each census year }\end{array}$ & $\mathrm{TpEg}$ \\
\hline Glossy Ibis population size & $\begin{array}{l}\text { Number of breeding pairs of Glossy Ibis }(P . \text { falcinellus }) \text { for } \\
\text { each census year }\end{array}$ & TpPf \\
\hline
\end{tabular}


30-year study period because only the 2012 update of maps was available. Nevertheless, as these environments are stable on the surface, we assumed that the difference in the total area occupied by each land use type over the years was not likely to significantly or substantially modify the results. We evaluated the relation between the habitat characteristic and the annual number of breeding pairs in each wetland with a Correspondence Analysis (CA) which, from a graphical point of view, allows the possible relations between a set of variables to be analysed. In this case, wetlands were compared in each census year (rows) with the selected variables and the population size of each species (columns). This analysis was run with version 3.14 of the Past3 programme (Hammer et al., 2001).

\section{RESULTS}

\section{Population trends}

All the study species showed a growing trend between 1984 and 2015 (Table 2). For no species

Table 2. Trends of the breeding populations of all the species in the studied wetlands in the long (32 years), mid (16 years) and short ( 8 years) terms, including slope (b), coefficient of determination $\left(\mathrm{r}^{2}\right)$ and the $p$ values. Tendencias de las poblaciones reproductivas de todas las especies en los humedales estudiados, considerando largo (32 años), mediano (16 años) y corto plazo ( 8 años). Se incluye la pendiente (b), el coeficiente de determinación ( $r^{2}$ ) y el valor de p. (MM: Marjal dels Moro, MA: Marjal de Almenara, MXX: Marjal XeresaXeraco, MHA: Marjal Hondo de Amorós, LANP: L'Albufera de Valencia Natural Park, PONP: Pego-Oliva Natural Park, SPNP: Salinas de Santa Pola Natural Park, EHNP: El Hondo Natural Park, EE: Embarcaderos Dam, EB: Beniarrés Dam, ELP: La Pedrera Dam)

\begin{tabular}{|c|c|c|c|c|c|c|c|c|c|c|c|c|c|c|c|c|c|c|c|}
\hline \multirow{3}{*}{ Wetland } & \multirow{3}{*}{ Years } & \multicolumn{18}{|c|}{ Heron Species } \\
\hline & & \multicolumn{3}{|c|}{ Grey Heron } & \multicolumn{3}{|c|}{ Purple Heron } & \multicolumn{3}{|c|}{ Squacco Heron } & \multicolumn{3}{|c|}{ Cattle Egret } & \multicolumn{3}{|c|}{ Little Egret } & \multicolumn{3}{|c|}{ Glossy Ibis } \\
\hline & & $\mathrm{b}$ & $\mathrm{r}^{2}$ & $p$ & $\mathrm{~b}$ & $\mathrm{r}^{2}$ & $p$ & $\mathrm{~b}$ & $\mathrm{r}^{2}$ & $p$ & $\mathrm{~b}$ & $r^{2}$ & $p$ & $\mathrm{~b}$ & $r^{2}$ & $p$ & $\mathrm{~b}$ & $\mathrm{r}^{2}$ & $p$ \\
\hline MM & $\begin{array}{c}32 \\
16 \\
8 \\
\end{array}$ & $\begin{array}{c}3.67 \\
12.29 \\
17.01\end{array}$ & $\begin{array}{l}0.64 \\
0.89 \\
0.91\end{array}$ & $\begin{array}{l}<0.01 \\
<0.01 \\
<0.01 \\
\end{array}$ & $\begin{array}{l}0.33 \\
0.14 \\
0,07\end{array}$ & $\begin{array}{c}0.46 \\
0.04 \\
0.003\end{array}$ & $\begin{array}{c}<0.01 \\
0.43 \\
0.88\end{array}$ & & & & $\begin{array}{c}1.02 \\
7.25 \\
11.25\end{array}$ & $\begin{array}{l}0.24 \\
0.50 \\
0.60\end{array}$ & $\begin{array}{l}0.02 \\
0.03 \\
0.04\end{array}$ & $\begin{array}{l}0.72 \\
4.15 \\
7.68\end{array}$ & $\begin{array}{l}0.27 \\
0.51 \\
0.66\end{array}$ & $\begin{aligned} & 0.01 \\
< & 0.01 \\
< & 0.01\end{aligned}$ & $\begin{array}{c}1.5 \\
9.08 \\
16.57\end{array}$ & $\begin{array}{l}0.35 \\
0.58 \\
0.69\end{array}$ & $\begin{array}{c}<0.01 \\
0.01 \\
0.04\end{array}$ \\
\hline MA & $\begin{array}{c}32 \\
16 \\
8\end{array}$ & & & & $\begin{array}{c}0.44 \\
0.54 \\
-0.78 \\
\end{array}$ & $\begin{array}{l}0.45 \\
0.17 \\
0.10\end{array}$ & $\begin{array}{c}<0.01 \\
0.14 \\
0.44\end{array}$ & $\begin{array}{l}0.56 \\
1.22 \\
0.26\end{array}$ & $\begin{array}{c}0.53 \\
0.29 \\
0.009\end{array}$ & $\begin{array}{c}<0.01 \\
0.08 \\
0.82\end{array}$ & $\begin{array}{l}0.88 \\
3.11 \\
4.14 \\
\end{array}$ & $\begin{array}{l}0.35 \\
0.41 \\
0.33\end{array}$ & $\begin{array}{c}<0.01 \\
0.03 \\
0.14\end{array}$ & $\begin{array}{l}1.77 \\
6.22 \\
6.96\end{array}$ & $\begin{array}{l}0.53 \\
0.55 \\
0.35\end{array}$ & $\begin{array}{c}<0.01 \\
0.01 \\
0.16\end{array}$ & & & \\
\hline MXX & $\begin{array}{c}32 \\
16 \\
8 \\
\end{array}$ & $\begin{array}{r}0.31 \\
0.09 \\
-1.38 \\
\end{array}$ & $\begin{array}{l}0.40 \\
0.01 \\
0.42\end{array}$ & $\begin{array}{c}<0.01 \\
0.68 \\
0.08\end{array}$ & $\begin{array}{l}0.76 \\
0.76 \\
1.20\end{array}$ & $\begin{array}{l}0.58 \\
0.44 \\
0.34\end{array}$ & $\begin{array}{c}<0.01 \\
<0.01 \\
0.13\end{array}$ & $\begin{array}{l}0.68 \\
1.90 \\
3.62\end{array}$ & $\begin{array}{l}0.51 \\
0.66 \\
0.70\end{array}$ & $\begin{array}{c}<0.01 \\
<0.01 \\
0.01\end{array}$ & $\begin{array}{l}0.72 \\
1.86 \\
1.36\end{array}$ & $\begin{array}{l}0.59 \\
0.60 \\
0.17\end{array}$ & $\begin{array}{c}<0.01 \\
<0.01 \\
0.31\end{array}$ & $\begin{array}{l}0.99 \\
3.54 \\
5.24\end{array}$ & $\begin{array}{l}0.50 \\
0.70 \\
0.67\end{array}$ & $\begin{array}{c}<0.01 \\
<0.01 \\
0.01\end{array}$ & $\begin{array}{l}0.22 \\
1.42 \\
2.71\end{array}$ & $\begin{array}{l}0.27 \\
0.47 \\
0.58\end{array}$ & $\begin{array}{l}0.02 \\
0.04 \\
0.08\end{array}$ \\
\hline MHA & 8 & & & & & & & & & & 56.79 & 0.31 & 0.19 & & & & 5.86 & 0.31 & 0.25 \\
\hline LANP & $\begin{array}{c}32 \\
16 \\
8 \\
\end{array}$ & $\begin{array}{l}13.24 \\
-22.76 \\
-36.21\end{array}$ & $\begin{array}{l}0.29 \\
0.26 \\
0.27\end{array}$ & $\begin{array}{c}<0.01 \\
0.04 \\
0.19\end{array}$ & $\begin{array}{r}-0.85 \\
-0.77 \\
5.81\end{array}$ & $\begin{array}{l}0.14 \\
0.06 \\
0.82\end{array}$ & $\begin{array}{c}0.03 \\
0.37 \\
<0.01\end{array}$ & $\begin{array}{l}11.63 \\
11.92 \\
46.06\end{array}$ & $\begin{array}{l}0.61 \\
0.21 \\
0.49\end{array}$ & $\begin{array}{c}<0.01 \\
0.07 \\
0.05\end{array}$ & $\begin{array}{c}15.32 \\
-137.59 \\
-310.58\end{array}$ & $\begin{array}{l}0.03 \\
0.54 \\
0.70\end{array}$ & $\begin{array}{c}0.38 \\
<0.01 \\
0.01\end{array}$ & $\begin{array}{c}20.55 \\
-23.18 \\
-37.11\end{array}$ & $\begin{array}{l}0.14 \\
0.08 \\
0.08\end{array}$ & $\begin{array}{l}0.04 \\
0.29 \\
0.51\end{array}$ & $\begin{array}{c}4.00 \\
21.77 \\
34.43\end{array}$ & $\begin{array}{l}0.55 \\
0.85 \\
0.98\end{array}$ & $\begin{array}{l}<0.01 \\
<0.01 \\
<0.01 \\
\end{array}$ \\
\hline PONP & $\begin{array}{c}32 \\
16 \\
8\end{array}$ & $\begin{array}{c}0.57 \\
0.10 \\
-2.63\end{array}$ & $\begin{array}{c}0.29 \\
0.002 \\
0.32\end{array}$ & $\begin{array}{c}<0.01 \\
0.84 \\
0.14\end{array}$ & $\begin{array}{c}0.73 \\
-0.67 \\
-3.12 \\
\end{array}$ & $\begin{array}{l}0.21 \\
0.06 \\
0.27\end{array}$ & $\begin{array}{l}0.01 \\
0.35 \\
0.18\end{array}$ & $\begin{array}{l}0.59 \\
0.89 \\
0.13\end{array}$ & $\begin{array}{c}0.76 \\
0.61 \\
0.007\end{array}$ & $\begin{array}{c}<0.01 \\
<0.01 \\
0.85\end{array}$ & $\begin{array}{l}0.72 \\
1.63 \\
0.46\end{array}$ & $\begin{array}{l}0.49 \\
0.20 \\
0.01\end{array}$ & $\begin{array}{c}<0.01 \\
0.20 \\
0.80\end{array}$ & $\begin{array}{l}2.71 \\
8.42 \\
7.40\end{array}$ & $\begin{array}{l}0.53 \\
0.49 \\
0.22 \\
\end{array}$ & $\begin{array}{c}<0.01 \\
0.02 \\
0.24\end{array}$ & & & \\
\hline SPNP & $\begin{array}{c}32 \\
16 \\
8 \\
\end{array}$ & $\begin{array}{c}1.11 \\
-0.66 \\
-7.25 \\
\end{array}$ & $\begin{array}{l}0.32 \\
0.02 \\
0.56\end{array}$ & $\begin{array}{c}<0.01 \\
0.69 \\
0.05\end{array}$ & $\begin{array}{l}-0.38 \\
-1.75 \\
-0.07 \\
\end{array}$ & $\begin{array}{c}0.11 \\
0.33 \\
0.007\end{array}$ & $\begin{array}{l}0.11 \\
0.05 \\
0.84\end{array}$ & $\begin{array}{c}1.70 \\
0.36 \\
-4.06 \\
\end{array}$ & $\begin{array}{c}0.41 \\
0.004 \\
0.15\end{array}$ & $\begin{array}{c}<0.01 \\
0.85 \\
0.34\end{array}$ & $\begin{array}{c}49.85 \\
-52.00 \\
-193.87\end{array}$ & $\begin{array}{l}0.36 \\
0.09 \\
0.32\end{array}$ & $\begin{array}{c}<0.01 \\
0.33 \\
0.14\end{array}$ & $\begin{array}{l}-0.76 \\
-0.61 \\
-5.54 \\
\end{array}$ & $\begin{array}{c}0.01 \\
0.008 \\
0.31\end{array}$ & $\begin{array}{l}0.71 \\
0.76 \\
0.19\end{array}$ & $\begin{array}{r}1.33 \\
1.48 \\
-3.23 \\
\end{array}$ & $\begin{array}{l}0.46 \\
0.10 \\
0.15\end{array}$ & $\begin{array}{c}<0.01 \\
0.30 \\
0.34\end{array}$ \\
\hline EHNP & $\begin{array}{c}32 \\
16 \\
8\end{array}$ & $\begin{array}{l}0.64 \\
7.75 \\
7.75\end{array}$ & $\begin{array}{l}0.18 \\
0.53 \\
0.53\end{array}$ & $\begin{array}{c}0.06 \\
0.06 \\
<0.01 \\
\end{array}$ & $\begin{array}{r}-0.43 \\
-0.99 \\
1.76 \\
\end{array}$ & $\begin{array}{l}0.12 \\
0.10 \\
0.30\end{array}$ & $\begin{array}{l}0.07 \\
0.28 \\
0.16 \\
\end{array}$ & $\begin{array}{c}3.48 \\
19.5 \\
24.36\end{array}$ & $\begin{array}{l}0.54 \\
0.63 \\
0.69 \\
\end{array}$ & $\begin{array}{c}<0.01 \\
0.02 \\
0.02\end{array}$ & $\begin{array}{c}37.98 \\
328.81 \\
500\end{array}$ & $\begin{array}{l}0.24 \\
0.48 \\
0.74\end{array}$ & $\begin{array}{l}0.02 \\
0.06 \\
0.01\end{array}$ & $\begin{array}{c}2.74 \\
55.94 \\
69.64 \\
\end{array}$ & $\begin{array}{l}0.05 \\
0.70 \\
0.77\end{array}$ & $\begin{array}{l}0.33 \\
0.01 \\
0.01\end{array}$ & $\begin{array}{c}1.78 \\
14.38 \\
17.75\end{array}$ & $\begin{array}{l}0.30 \\
0.60 \\
0.64\end{array}$ & $\begin{array}{l}0.01 \\
0.02 \\
0.03\end{array}$ \\
\hline $\mathbf{E E}$ & 8 & 1.39 & 0.70 & 0.01 & & & & & & & & & & & & & & & \\
\hline EB & $\begin{array}{c}32 \\
16 \\
8 \\
\end{array}$ & $\begin{array}{c}0.91 \\
1.5 \\
1.5\end{array}$ & $\begin{array}{l}0.96 \\
0.75 \\
0.75\end{array}$ & $\begin{array}{c}<0.01 \\
0.33 \\
0.67\end{array}$ & & & & & & & & & & & & & & & \\
\hline ELP & $\begin{array}{c}32 \\
16 \\
8 \\
\end{array}$ & & & & & & & $\begin{array}{c}0.31 \\
-0.14 \\
-1.4 \\
\end{array}$ & $\begin{array}{c}0.60 \\
0.005 \\
0.56\end{array}$ & $\begin{array}{c}<0.01 \\
0.87 \\
0.08\end{array}$ & $\begin{array}{c}3.19 \\
17.79 \\
10.91\end{array}$ & $\begin{array}{l}0.66 \\
0.48 \\
0.28\end{array}$ & $\begin{array}{c}<0.01 \\
0.08 \\
0.28\end{array}$ & & & & & & \\
\hline $\begin{array}{l}\text { Valencia } \\
\text { Region }\end{array}$ & $\begin{array}{c}32 \\
16 \\
8\end{array}$ & $\begin{array}{c}18.53 \\
-9.90 \\
-16.62\end{array}$ & $\begin{array}{l}0.48 \\
0.06 \\
0.07\end{array}$ & $\begin{array}{c}<0.01 \\
0.36 \\
0.51\end{array}$ & $\begin{array}{c}1.03 \\
-0.68 \\
5.39\end{array}$ & $\begin{array}{l}0.13 \\
0.02 \\
0.44\end{array}$ & $\begin{array}{l}0.04 \\
0.62 \\
0.07\end{array}$ & $\begin{array}{l}17.39 \\
26.94 \\
69.46\end{array}$ & $\begin{array}{l}0.73 \\
0.54 \\
0.70\end{array}$ & $\begin{array}{c}<0.01 \\
<0.01 \\
0.01\end{array}$ & $\begin{array}{c}102.33 \\
39.10 \\
-4.75\end{array}$ & $\begin{array}{c}0.55 \\
0.04 \\
0.0004\end{array}$ & $\begin{array}{l}0.01 \\
0.46 \\
0.96\end{array}$ & $\begin{array}{c}26.48 \\
9.8 \\
48.21\end{array}$ & $\begin{array}{l}0.23 \\
0.02 \\
0.16\end{array}$ & $\begin{array}{c}<0.01 \\
0.63 \\
0.33\end{array}$ & $\begin{array}{l}83.42 \\
22.35 \\
53.68\end{array}$ & $\begin{array}{l}0.44 \\
0.66 \\
0.87\end{array}$ & $\begin{array}{l}<0.01 \\
<0.01 \\
<0.01\end{array}$ \\
\hline
\end{tabular}



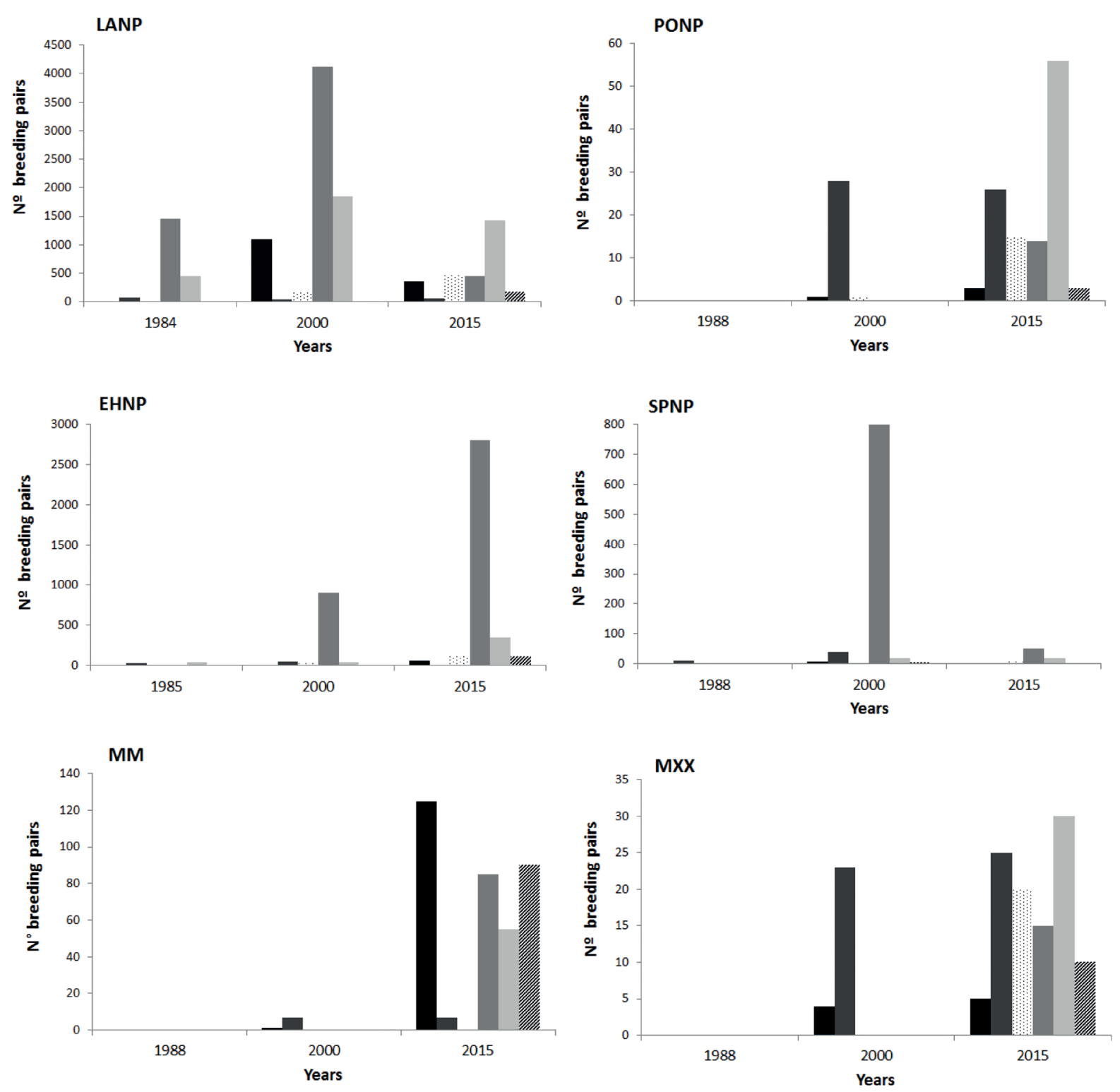

Figure 2. Number of breeding pairs per species at three different times during the 1984-2015 period for six wetlands in the study area. Número de parejas reproductivas por especie en tres diferentes momentos entre el periodo 1984-2015 para seis humedales del área de estudio. ( $\square$ Grey Heron-Garza Real $\square$ Cattle Egret-Garcilla bueyera $\square$ Purple Heron-Garza Imperial $\square$ Little Egret-Garceta

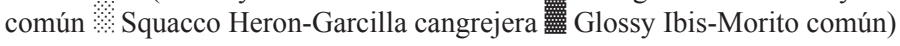

was an autocorrelation found between the numbers of nesting pairs in two consecutive years. Indeed, the $p$ of the linear trend was always $\leq 0.01$ in those cases for which the coefficient of autocorrelation was $>0.80$. Therefore, we considered that there was no autocorrelation.

Locally, the Purple Heron and Little Egret obtained the lowest $\mathrm{r}^{2}$ values that were, however, significant in the long term (Table 2). For wetlands, all the species in all the localities showed significant positive trends, except for the Purple Heron, which showed a negative trend in SPNP, EHNP and LANP, which was significant only in LANP (Table 2). The Little Egret present- 
ed no significant trend in EHNP or SPNP, nor did the Cattle Egret in LANP or MHA (Table 2). When considering the 16- and 8-year periods, throughout the Valencia Community only the Squacco Heron and Glossy Ibis continued to show a significant positive trend (Table 2). By analysing trends for wetlands, in the EHNP all species showed a significant trend in the mid and short terms, except for the Purple Heron (Table 2). The Grey Heron, Cattle Egret, Little Egret and Glossy Ibis showed a significant positive trend for both periods in MM, while the Squacco Heron and Little Egret did so in MXX (Table 2). In LANP, only the Glossy Ibis displayed positive trends in both the mid and short terms, whereas the Cattle Egret showed a significant negative trend during both periods, and the Grey Heron presented a negative trend during the 16-year period (Table 2).

\section{Fluctuations in species composition}

During the 30-year census, species richness and abundance has varied in each wetland. At the beginning of the census, breeding colonies were recorded only in LANP, EHNP and SPNP (Fig. 2). In 1984, LANP had colonies of Cattle Egret (most abundant), Little Egret, and Purple Heron (least abundant). Although the Grey heron has nested in the park since 1984, the few pairs (13) are not visible in the graph (Fig. 2). For this initial period, pairs of Purple Heron, Little Egret, Grey Heron, and one pair of Cattle Egret, were recorded in EHNP, and 10 pairs of Purple Heron were present in SPNP (Fig. 2).

Halfway through the period (2000), the Purple Heron had the most breeding pairs in MM, MXX and PONP, and a few Grey Heron pairs also settled in MM and PONP (Fig. 2). In EHNP, Cattle Egret was one of the most abundant species (as in SPNP and LANP), followed by the Purple Heron, Little Egret and Squacco Heron (Fig. 2).

In the last census (2015), all the species were present in all the monitored wetlands, except for the Squacco Heron, which was missing in MM, as was the Glossy Ibis in PONP (Fig. 2). The Little Egret was the dominant species in LANP, PONP an MXX, while it was the Grey heron in MM. The Cattle egret remained the most abundant breeding species in SPNP and EHNP (nearby localities; Fig. 2). The Cattle egret population diminished in LANP and became the third most abundant species after the Squacco Heron (Fig. 2). The Glossy Ibis has colonised the studied wetlands only recently and its biggest breeding population was found in LANP in 2015.

\section{Relations among populations}

The breeding populations of all the species present in LANP were significantly larger than the nesting populations of the same species in the other wetlands, except for the Glossy Ibis (Fig. 3 ), which indicates that it is the most important breeding colony of all those studied. For the Grey Heron, only the LANP population was significantly larger than in any other wetland. Otherwise, the EHNP and SPNP colonies were the second most important ones. The number of breeding pairs of Squacco Heron, Cattle Egret and Little Egret in these wetlands were significantly higher than for the other marshes, but their abundances did not differ from one another (Fig. 3). The Purple Heron showed significant differences among several populations (Fig. 3).

The breeding populations of the Squacco Heron and Grey Heron in the different localities correlated positively and significantly in most cases (Table 3). The breeding populations of the Cattle Egret and Little Egret in LANP showed no relation with any of these populations in other localities, while the other species correlated with the populations of MM, MXX, PONP and SPNP to a greater or lesser extent. The Purple Heron correlated negatively with the MM population (Table 3). All the nesting species in MXX correlated significantly with the species of PONP, except for the Purple Heron and Glossy ibis. Likewise, the population sizes of all the species present in MA significantly correlated with those of PONP and MXX (Table 3).

\section{Habitat variables}

In the CA, $82.14 \%$ of total variance was explained on the first three axes $(67.18 \%$ on the first two). On the first axis (42.24\%), the variables with a greater weight in positive absolute values $(>1)$ were Distance to the L'Albufera NP (DistPNLA), 

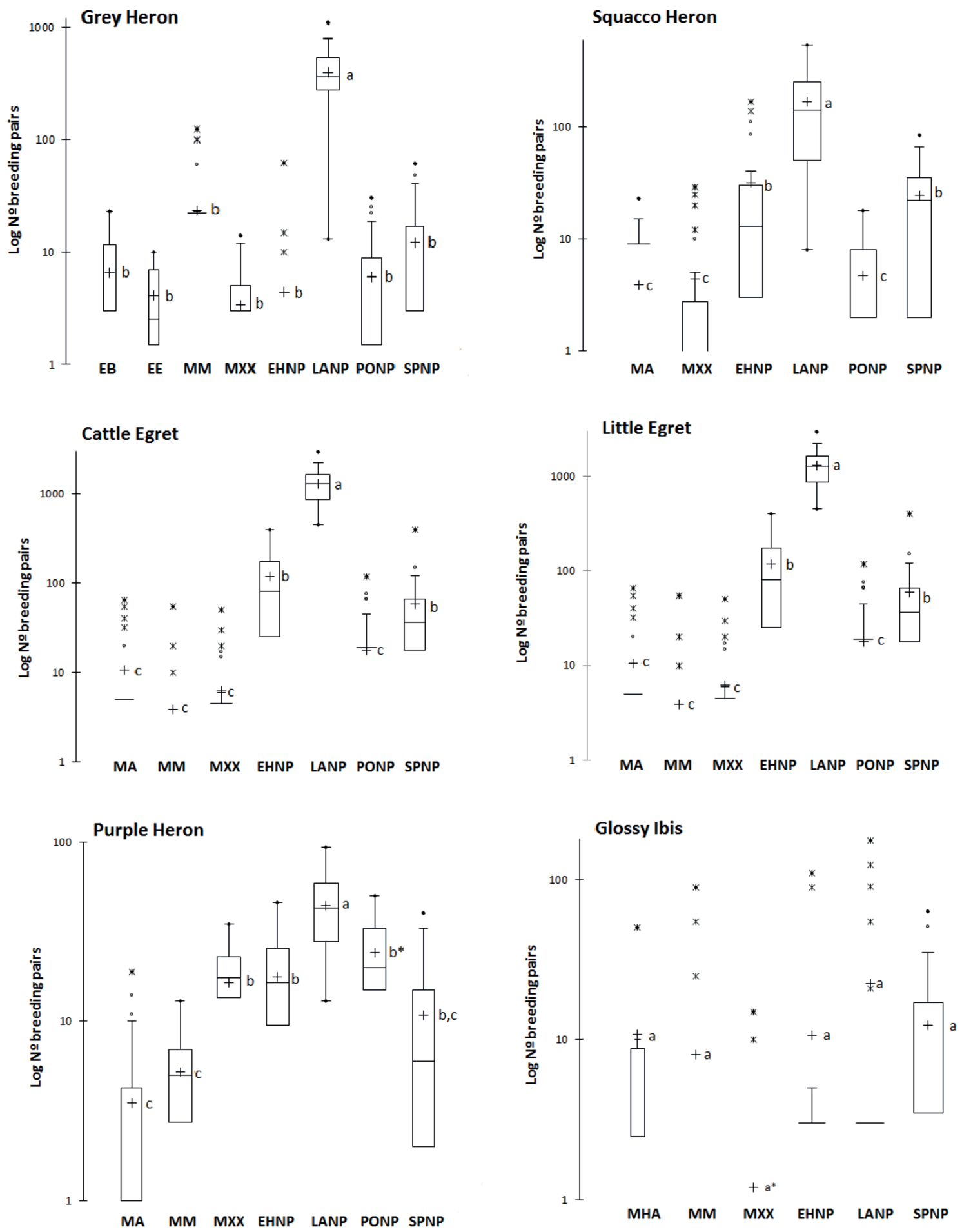

Figure 3. Nesting pairs per species between 1984 and 2015 in each studied wetland $(+$ mean, $\bullet$ minimum/maximum, - median, T standard deviation, $\bigcirc$ atypical values $*$ extreme values. Same word: no significant differences, different word: significant differences. $\mathrm{a}^{*} \mathrm{~b}^{*}$ only significantly differs from SPNP). Parejas nidificantes por especie entre 1984 y 2015 en cada humedal estudiado (+ media, - mínimo/máximo, - mediana, T desviación estándar, $\bigcirc$ valores atípicos $*$ valores extremos. Letras iguales: no hay diferencias significativas, letras diferentes: hay diferencias significativas. $a^{*} b^{*}$ solo difieren significativamente de SPNP). 
Precipitation (PP), Temperature (Temp), Protection category, Protection, Marshes, Other Vegetation, Other Crops, Beaches and Urbanism. Towards the negative side of the axis, the variables with the greatest weight were Water $10 \mathrm{~km}$ and Rice $15 \mathrm{~km}$. However, Total area, Rice $5 \mathrm{~km}$ and Water $10 \mathrm{~km}$ (the other negative values on the axis) contributed to pull the population size variables of the Grey Heron, Little Egret, Squacco Heron and Cattle Egret towards this sector (Fig. 4). The LANP and EE wetlands were also located slightly towards the negative side of the axis, which were the two wetlands with the largest (total) area of those herein considered (Fig. 4). The population sizes of the Purple Heron and Glossy Ibis were associated with the variables located in the positive sector of axis 1, like marshes (MA, MM, MXX, MHA) and PONP (Fig. 4). The dispersion of points was basically due to the difference in rainfall in several years, and it was one of the variables with a greater weight (positive absolute value) on this axis. Marshes, mainly MM, MXX, MA and PONP, were apparently associated with the presence of Other Crops (not rice), Other Vegetation (non-forest), Urbanism, Marshes and Beaches (Fig. 4).

For axis 2, of the variables with a greater

Table 3. Statistic and $p$ values of the Correlation Analysis between the populations of each heron species in the different studied wetlands. Valor del estadístico y p del Análisis de Correlación entre las poblaciones de cada especie de garza en los diferentes humedales estudiados.

\begin{tabular}{lcccccccc}
\multicolumn{2}{c}{ Grey Heron } & \multicolumn{1}{c}{} & \multicolumn{1}{c}{} & \\
\hline St $\boldsymbol{p}$ & PONP & MXX & EB & SPNP & EHNP & LANP & MM & EE \\
\hline PONP & & $<0.0001$ & 0 & $<0.001$ & 0.07 & $<0.01$ & $<0.0001$ & 1 \\
MXX & 0.86 & & 0 & $<0.001$ & 0.19 & $<0.001$ & $<0.01$ & 1 \\
EB & 0 & 0 & & 0 & 1 & 0.12 & 0 & 1 \\
SPNP & 0.83 & 0.78 & 0 & & 1 & 0.28 & $<0.01$ & 1 \\
EHNP & 0.64 & 0.58 & 0.11 & 0.37 & & 0.25 & 0.04 & 1 \\
LANP & 0.64 & 0.74 & 0.78 & 0.54 & 0.57 & & 0.05 & 1 \\
MM & 0.88 & 0.73 & 0 & 0.73 & 0.66 & 0.60 & & 1 \\
EE & 0 & 0 & 0.86 & 0 & 0.25 & 0.69 & 0 & \\
\hline
\end{tabular}

Purple Heron

\begin{tabular}{lccccccc}
\hline $\mathbf{S t} \backslash \mathbf{p}$ & MM & MXX & PONP & SPNP & MA & EHNP & LANP \\
\hline MM & & 0.27 & 1 & 1 & 0.05 & 1 & 0.04 \\
MXX & 0.46 & & 0.18 & 1 & 0.03 & 1 & 0.78 \\
PONP & 0.19 & 0.49 & & 1 & $<0.0001$ & 1 & 1 \\
SPNP & -0.07 & -0.27 & -0.22 & & 1 & 1 & 1 \\
MA & 0.59 & 0.62 & 0.86 & -0.39 & & 1 & 1 \\
EHNP & -0.15 & -0.30 & -0.13 & 0.15 & -0.18 & & 1 \\
LANP & -0.56 & -0.40 & -0.07 & -0.20 & -0.21 & -0.28 & \\
\hline
\end{tabular}

Squacco Heron

\begin{tabular}{lccccccc}
\hline St $\backslash \mathbf{p}$ & PONP & MXX & MA & SPONP & EHNP & LANP & ELP \\
\hline PONP & & $<0.0001$ & $<0.0001$ & 1 & $<0.001$ & $<0.01$ & 0.35 \\
MXX & 0.91 & & $<0.0001$ & 1 & $<0.001$ & 0.02 & 1 \\
MA & 0.91 & 0.97 & & 0.04 & 0.02 & 0.12 & 1 \\
SPONP & 0.38 & 0.33 & 0.64 & & 1 & $<0.01$ & 0.3 \\
EHNP & 0.75 & 0.76 & 0.67 & 0.03 & & 1 & 1 \\
LANP & 0.69 & 0.62 & 0.58 & 0.68 & 0.38 & & 1 \\
ELP & 0.57 & 0.43 & 0.43 & 0.58 & 0.17 & 0.37 & \\
\hline
\end{tabular}

Cattle Egret

\begin{tabular}{lccccccccc}
\hline St $\backslash p$ & MM & MXX & PONP & SPNP & MA & EHNP & LANP & ELP & MHA \\
\hline MM & & 0.06 & 0.24 & 1 & 0.77 & 0.16 & 1 & 0 & 1 \\
MXX & 0.63 & & $<0.0001$ & 1 & $<0.0001$ & 1 & 0.49 & 1 & 1 \\
PONP & 0.56 & 0.94 & & 1 & $<0.0001$ & 1 & 0.16 & 1 & 1 \\
SPNP & 0.07 & 0.37 & 0.38 & & 0.04 & 1 & 0.05 & 0.07 & 1 \\
MA & 0.50 & 0.85 & 0.86 & 0.66 & & 1 & 0.16 & 0.87 & 1 \\
EHNP & 0.58 & 0.09 & 0.05 & 0.05 & 0.14 & & 1 & 1 & 1 \\
LANP & 0.25 & 0.49 & 0.57 & 0.63 & 0.60 & -0.03 & & 0.87 & 1 \\
ELP & 0 & 0.50 & 0.50 & 0.70 & 0.54 & 0.19 & 0.54 & & 1 \\
MHA & 0 & 0 & 0 & 0.67 & 0 & 0.67 & -0.52 & 0 & \\
\hline
\end{tabular}

Little Egret

\begin{tabular}{lccccccc}
\hline Stlp & MM & MXX & PONP & SPNP & MA & EHNP & LANP \\
\hline MM & & $<0.01$ & 0.03 & 1 & 1 & 1 & 1 \\
MXX & 0.72 & & $<0.0001$ & 1 & $<0.0001$ & 1 & 0.54 \\
PONP & 0.64 & 0.91 & & 1 & $<0.0001$ & 1 & 0.38 \\
SPNP & 0.11 & -0.04 & 0.06 & & 1 & 1 & 1 \\
MA & 0.29 & 0.97 & 0.86 & 0.13 & & 0.35 & 1 \\
EHNP & 0.42 & 0.06 & -0.01 & 0.09 & -0.53 & & 1 \\
LANP & 0.32 & 0.45 & 0.49 & 0.26 & 0.16 & 0.26 & \\
\hline
\end{tabular}

Glossy Ibis

\begin{tabular}{ccccccc}
\hline St $\backslash \mathbf{p}$ & MM & MXX & MHA & SPNP & EHNP & LANP \\
\hline MM & & $<0.0001$ & 1 & 0.03 & 0.04 & $<0.01$ \\
MXX & 0.79 & & 1 & 0.21 & 0.57 & 0.09 \\
MHA & 0.00 & 0 & & 1 & 1 & 1 \\
SPNP & 0.63 & 0.53 & 0 & & $<0.01$ & $<0.01$ \\
EHNP & 0.64 & 0.47 & 0 & 0.77 & & 0.06 \\
LANP & 0.69 & 0.58 & 0.42 & 0.69 & 0.62 & \\
\hline
\end{tabular}




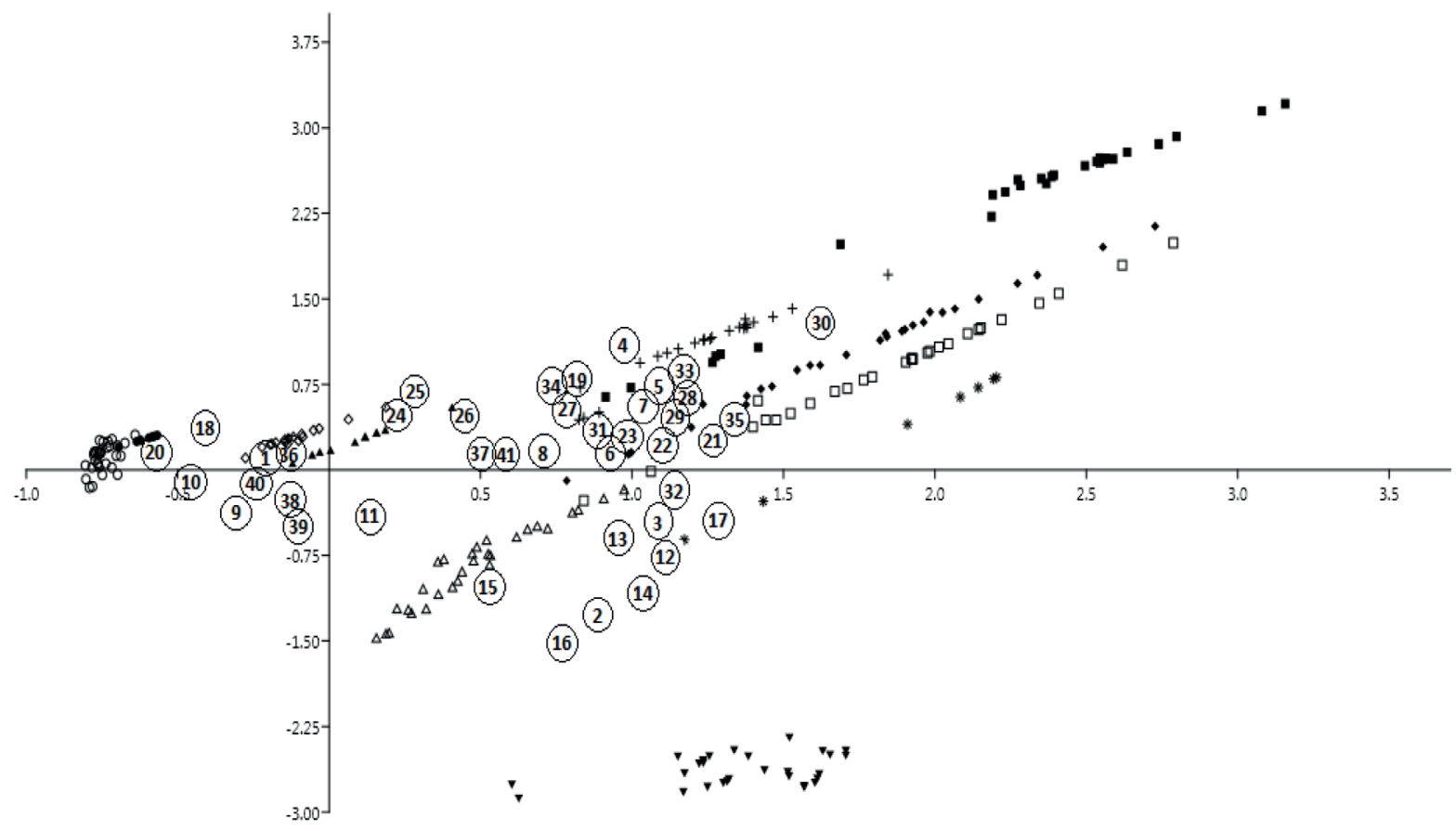

Figure 4. Correspondence analysis showing the relations between the studied wetlands and variables. Análisis de correspondencia mostrando la relación entre los humedales y entre las variables estudiadas. Wetlands- Humedales: $\square \mathrm{MM} \square \mathrm{MXX}+\mathrm{MA} * \mathrm{MHA}$ $\diamond \mathrm{PONP} \bigcirc \mathrm{LANP} \triangle \mathrm{SPNP} \boldsymbol{\nabla} \mathrm{EHNP} \bullet \mathrm{EE} \boldsymbol{\Delta} \mathrm{EB} \diamond \mathrm{ELP} /$ Variables: 1 TotalArea, 2 MarshesArea, 3 Dist.PNLA, 4 Dist. PNEH, 5 PPm, 6 Temp, 7 Category, 8 Protection, 9 Water5Km, 10 Water10Km, 11 Water15Km, 12 Marshes5Km, 13 Marshes10Km, 14 Marshes15Km, 15 Sal5Km, 16 Sal10Km, 17 Sal15Km, 18 Rice5Km, 19 Rice10Km, 20 Rice15Km, 21 OtherCrops5Km, 22 OtherCrops10Km, 23 OtherCrops15Km, 24 Forest5Km, 25 Forest10Km, 26 Forest15Km, 27 OtherVeg5Km, 28 OtherVeg10Km, 29 OtherVeg15Km, 30 Urb5Km, 31 Urb10Km, 32 Urb15Km, 33 Beach5Km, 34 Beach10Km, 35 Beach15Km, 36 TpAc, 37 TpAp, 38 TpAr, 39 TpBi, 40 TpEg, 41 TpPf.

negative weight, which seemed to characterise environments, we found Saltpans and Marshes, which led SPNP and EHNP to be located towards this sector of the axis (Fig. 4).

\section{DISCUSSION}

The results of this study confirm that the reproductive populations of the six considered species have increased in the last three decades. However, this increase appears to have stopped in the last half of the period, except for the Squacco Heron and Glossy Ibis. Moreover, the Grey Heron, Cattle Egret, Little Egret and Squacco Heron species seem to be associated with the environments characterised by having a bigger area, nearby freshwater bodies and the presence of rice fields. The Purple Heron and Glossy Ibis species would be associated with environments influenced mostly by rainfall and with some form of protection. Of all these variables, management of water bodies and rice fields, and administration of protected areas, would be those to consider when devising conservation plans for these species.

Between 1984 and 2014, $80 \%$ of the reproductive water bird species in the Valencian Community, such as ducks, grebes and seagulls, have increased, of which $21 \%$ are herons (MartinezAbraín et al., 2016; Garrido et al., 2012). All our heron species have displayed an increasing breeding population trend in the last 30 years, which has also been observed in Doñana (SW Spain) over the 1984-2010 period (Ramo et al., 2013) The populations of these species have increased in western Mediterranean wetlands since the 1970s (Galewski et al., 2011). The breeding 
populations of the Purple Heron, Grey Heron, Cattle Egret and Little Egret have displayed a significant positive trend, but not in the last 16 and 8 study years. Garrido et al. (2012) mentioned that in the Valencian Community, the Little Egret population seems to have stabilised in the last 10 years prior to their study (between 2000 and 2010) following a growth phase in the 1990s. A coherent trend has also been observed in the populations of the Grey Heron and Little Egret in NW Italy (Fasola et al., 2010). MartinezAbraín et al. (2016) found that the population trends of the Cattle Egret and Little Egret in the Valencian Community fit the logistic growth curve, which would be consistent with the fact that they have stopped showing a positive trend in the last 16 years. According to the same author, this would suggest that these species have recovered after the critical situation they were in at the beginning of the study, which was caused by the poor conditions of wetlands, and would have reached their carrying capacity. Their work also mentions that the Squacco Heron and Glossy Ibis are going through an exponential growth phase as they are the most recent colonisation (MartinezAbraín et al., 2016). This would coincide with the fact that these species displayed significant increasing trends in all the considered wetlands throughout our study period. In 2016, both species had more than 700 pairs distributed in eight different localities, which denotes their extended local distribution (Generalitat Valenciana, 2016).

Although the Cattle Egret has maintained a significant growing trend in the Valencian Community, when considering the whole period, it has displayed a decreasing trend in recent years in LANP. However, it has increased in other wetlands, especially in EHNP, which compensates local declines thanks to their increasing numbers in nearby areas (Garrido et al., 2012).

The breeding populations of all the studied species in LANP were significantly more numerous than those in the other wetlands, and were the first colonies to be established in the region, which confirms the importance of this wetland for the reproduction of this species group. The Purple Heron was the first species to colonise the wetlands closest to LANP from the 1990s to a decade later, when other species began to arrive.
The colony being established could be conditioned by the state of vegetation, which would offer adequate coverage and density (Santoro et al., 2010), along with the presence of a small population to attract other individuals of the same species or of others (Pechuan, 1971; Prosper, 2000; Delord et al., 2003; Santoro et al., 2010). The last in this group of wetlands to be colonised was MM. In the wetlands of MXX and PONP, which are close to one another, the Purple Heron is the second most abundant species. Therefore, these protected areas play an important role in this species' conservation, considered to be Vulnerable in the Valencia Catalogue of Endangered Fauna Species.

Between 2006 and 2016, the most numerous nesting populations in LANP have dropped by $43 \%$ due to the declining number of pairs of the Grey Heron, Little Egret and Cattle Egret (Generalitat Valenciana, 2016). However, populations have considerably increased in EHNP and, together with SPNP, could be concentrating part of the breeding population of the Cattle Egret and Little Egret of LANP. (Generalitat Valenciana, 2016). The number of both the Cattle Egret nests and Little Egret colonies is positively associated with the area occupied by rice fields (Tourenq et al., 2000), and they depend on water conditions and variations in water quality (Hafner et al., 1987; Bartolomé et al., 1997; Garrido et al., 2012). Therefore, the decline in the Cattle Egret and Little Egret populations in LANP could be indicative of a deterioration in rice field conditions as this variable characterises this wetland. In contrast, both species are present in larger numbers in EHNP, which may be a response to better water management (Generalitat Valenciana, 2016). The EHNP from 2011-2012 made improvements to the hydraulic infrastructure and changes in water management, which have favoured the increased quantity and quality of the water bodies in the park (Generalitat Valenciana, 2012). These species have benefited from this management as they find more water resources (marshes, ponds, irrigation canals), where they can further use as feeding areas. These water bodies have been shown an important association with size of colonies and these species' reproductive success (Hafner et al., 1987; Bartolome et al., 
1997; Parejo et al., 2001; Garrido et al., 2012).

Most wetlands are characterised by the presence or proximity of other types of crops, shrub and grassland type vegetation (non-forests), urbanism and industry, marshes and beaches, especially coastal wetlands like MM, MXX, MA and PONP. Rainfall seems to considerably influence the environment of marshes as this variable causes different flood conditions, which would determine the availability of feeding areas in different years (Bancroft et al., 1988; Hafner et al., 1994). Colony size and reproductive success are positively related to the freshwater habitat area, which constitutes their feeding habitat and this, in turn, is affected by rainfall (Hafner et al., 1987; Hafner et al., 1994, Bennets et al., 2000, Ramo et al., 2013).

Spring rains would potentially have a stronger effect on these natural wetlands than on artificial ones (rice fields) like LANP (Sánchez-Guzmán et al., 2007; Fasola et al., 2010).

Four of the studied species (Grey Heron, Little Egret, Cattle Egret, Squacco Heron) were associated with the presence of rice fields and freshwater bodies, and with the total site area. This species may prefer similar environments to nests, where these three variables are the most important. Of these, the Grey Heron seems to be more associated with rice fields than the other three species, whereas the remaining three appear to be slightly more associated with permanent marshes (Hafner et al., 1987). Rice fields are an important source of food for many waterfowl species, including herons and ibises (Fasola \& Ruiz, 1996; Prosper \& Hafner, 1996; Generalitat Valenciana, 2002b; Toral et al., 2012), especially during the reproductive period when paddies relate positively to the size of breeding colonies (Hafner et al., 1987; Lekuona, 2002). LANP, in addition to rice fields, is also characterised as the most extensive total area of the considered wetlands. This would explain why LANP is the site with the most breeding pairs (Pérez-Aranda et al., 2003; Garrido et al., 2012; Generalitat Valenciana, 2013). However, certain factors like reducing the flooding period or winter drainage intensification for soil preparation can negatively affect these species' populations (Prosper \& Hafner, 1996; Ibañez et al., 2010).
The Purple Heron and Glossy Ibis are more associated with marshes, which are, in turn, associated with rainfall (Toral et al., 2012). These species seem to have a closer relation with protecting nesting areas. This relation is particularly important for the endangered Purple Heron, which has been able to recover only in recent years. In NW Italy, the protection status of breeding colonies was significantly related to population trends, as were feeding habitats (Fasola et al., 2010). In our case, some species had permanently established in some wetlands 2-4 years after being declared protected areas.

The increase in heron populations, including threatened or vulnerable species, highlights the importance and effectiveness of conservation initiatives and protection policies, which are more critical locally during the reproductive season (Generalitat Valenciana, 2013; MartinezAbraín et al., 2016).

Reproductive success is typically higher in the colonies surrounded by rice fields and freshwater marshes (Hafner et al., 1987; Delord et al., 2003). Therefore, how paddies are managed will be a determining factor to maintain positive environmental externalities, such as the feeding, nesting and productivity of different bird species, including herons (Picazo-Tadeo et al., 2009). This is especially true for LANP, whose production is adapting to more competitive markets and an increasingly strong pressure on water resources distribution (Picazo-Tadeo et al., 2009). We also highlight the importance of conserving the wetland network (Red Natura, 2000) with management plans that incorporate measures for these nesting bird populations. Water management is a major aspect to consider in any management plan for these areas. Maintaining sufficiently flooded areas, which may be either artificial like rice fields or reservoirs, or natural like ponds and marshes, in breeding colonies' area of influence is vital for their conservation. The management plans of these protected areas should be reviewed to evaluate this aspect, and to invest, if necessary, in infrastructure and research to ensure good water resources management. These populations should always be considered a priority within the regional framework, and continuing with the typical metapopulations and source-sink dynam- 
ics processes that might occur must be ensured.

\section{ACKNOWLEDGMENTS}

The authors thank the Department of Agriculture, Environment, Climate Change and Rural Development (Consellería de Agricultura, Medio Ambiente, Cambio Climático y Desarrollo Rural) for providing 32 years of nesting water bird census data about the wetlands in the Valencian Community. We also thank the State Meteorological Agency (AEMET) for climate data. We would also like to thank to Simone Santoro and another anonymous reviewer, who kindly provided suggestions that helped improve the manuscript. Finally, we are grateful to Mario Palacios for his advice with statistical analyses, Carla Olmo and Tàlia Alabadí for their help with using GIS and analysing maps, and Marjorie Machado and Natalia Ceballos for their help with the manuscript.

\section{REFERENCES}

ATAURI, J. A. \& J. V. DE LUCIO. 2001. The role of landscape structure in species richness distribution of birds, amphibians, reptiles and lepidopterans in Mediterranean landscapes. Landscape Ecology, 16: 147-159. DOI: 10. 1023/A:1011115921050

BARTOLOMÉ, J., J. M. IGUAL, G. SARASA, J. R. GARRIDO \& J. M. CRUZ FERNANDEZ. 1997. Factores que influyen en la productividad de la garceta común (Egretta garzetta) y la garcilla bueyera (Bubulcus ibis) en Extremadura (SW de España). In: J. Manrique, A. Sánchez, F. Suarez y M. Yanez (Coords). Proceedings de las XII Jornadas Ornitológicas Españolas pp 23-32. Instituto de Estudios Almerinenses. Diputación de Almería. Almería.

BANCROFT, G. T., J. C. OGDEN \& B. W. PATTY. 1988. Wading bird colony formation and turnover relative to rainfall in the corkscrew swamp area of Florida during 1982 through 1985. The Wilson Bulletin, 100: 50-59. BIRDLIFE INTERNATIONAL. 2016. Ardea cinerea. The IUCN Red List of Threatened Species 2016: e.T22696993A86464489. DOI: 10.2305 / IUCN. UK. 2016 - 3. RL T S .
T22696993A86464489.en

BIRDLIFE INTERNATIONAL. 2016. Ardea purpurea. The IUCN Red List of Threatened Species 2016: e.T22697031A86466990. DOI: 10.2305 / IUCN.UK.2016-3.RL TS . T22697031A86466990.en

BIRDLIFE INTERNATIONAL. 2016. Ardeola ralloides. The IUCN Red List of Threatened Species 2016: e.T22697123A86450508. DOI: 10.2305/IUCN.UK.2016-3.RLTS.T22697123 A86450508.en

BIRDLIFE INTERNATIONAL. 2016. Bubulcus ibis. The IUCN Red List of Threatened Species 2016: e. T22697109A86454050. DOI: 10.2305 / IUCN.UK. $2016-3$. RL T S . T22697109A86454050.en

BIRDLIFE INTERNATIONAL. 2016. Egretta garzetta. The IUCN Red List of Threatened Species 2016: e.T62774969A86473701. DOI: $10.2305 /$ I UCN.UK. $2016-3$. RL T S . T62774969A86473701.en

BIRDLIFE INTERNATIONAL. 2016. Plegadis falcinellus. The IUCN Red List of Threatened Species 2016: e.T22697422A86436401. DOI: $10.2305 /$ I UCN.UK. $2016-3$. RL T S . T22697422A86436401.en

CONVENIO SOBRE CONSERVACIÓN DE LAS ESPECIES MIGRATORIAS DE LA FAUNA SILVESTRE. Decisión 82/461/CEE del Consejo de la Comunidad Europea. Apéndices I y II de la Convención sobre la conservación de las especies migratorias de animals silvestres (CMS). Available: https:// www.cms.int/sites/default/files/basic_page documents/appendices cop13 s 0. .pdf

CRAIG, R. J. \& K. G. BEAL. $19 \overline{92}$. The influence of habitat variables on marsh bird communities of the Connecticut River Estuary. The Willson Bulletin, 104: 295-311.

DECRETO 32/2004, de 27 de febrero, del Consell de la Generalitat, por el que se crea y regula el Catálogo Valenciano de Especies de Fauna Amenazadas, y se establecen categorías y normas para su protección. Available: http://www.dogv.gva.es/datos/2004/03/04/ pdf/2004_2170.pdf

DELORD, K., Y. KAYSER, C. BARBRAUD \& H. HAFNER. 2003. Variability in breeding parameters of the Squacco Heron Ardeola 
ralloides: Capsule breeding parameters and body condition of chicks varied with colony sites. Bird Study, 50: 300-305. DOI: 10.1080/ 00063650309461323

DIRECTIVA 2009/147/EC del Parlamento Europeo y del Consejo, de 30 de noviembre de 2009 , relativa a la conservación de aves silvestres. Available: https://www.boe.es/doue/ 2010/020/L00007-00025.pdf

FASOLA, M. \& X. RUIZ. 1996. The value of rice fields as substitutes for natural wetlands for waterbirds in the Mediterranean región. Colonial Waterbirds, 19: 122-128. DOI: 10.2307/ 1521955

FASOLA, M., D. RUBOLINI, E. MERLI, E. BONCOMPAGNI \& U. BRESSAN. 2010. Long-term trends of heron and egret populations in Italy, and the effects of climate, human-induced mortality, and habitat on population dynamics. Population Ecology, 52: 59-72.

FERRER-POLO, J., J. M. BENLLIURE, I. LACOMBA, A. BALLESTER, \& I. PRIETO. 2006. La restauración de los humedales costeros en la Comunidad Valenciana. Proceedings del III Congreso de Ingeniería Civil, Territorio y Medio Ambiente. Octubre 25-27, 2006. Zaragoza, España.

FIGUEROLA, J., M. MAÑEZ, F. IBAÑEZ, L. GARCIA \& H. GARRIDO. 2003. Morito común, Plegadis falcinellus. In: Atlas de las aves reproductoras de España. R. Marti \& J. C. Del Moral (eds.):124-125. Dirección General de Conservación de la Naturaleza. Sociedad Española de Ornitología. Madrid.

GALEWSKI, T., COLLEN, B., MCRAE, L., LOH. J., GRILLAS, P., GAUTHIERCLERC, M. \& V. DEVICTOR. 2011. Long-term trends in the abundance of Mediterranean wetland vertebrates: From global recovery to localized declines. Biological Conservation, 144: 1392-1399. DOI: 10.1016/ j.biocon.2010.10.030

GARRIDO, J. R, B. MOLINA, \& J. C. DEL MORAL. 2012. Las garzas en España, población reproductora e invernante en 2010-2011 y método de censo. SEO/BirdLife. Madrid.

GENERALITAT VALENCIANA. 2002a.
Catálogo de las Zonas Húmedas de la Comunidad Valenciana. Conselleria de Medio Ambiente. Valencia. España. Available:http:// www.agroambient.gva.es/es/web/espaciosnaturales-protegidos/fichas-de-la-1-a-la-48de-las-zonas-humedas-acceso-textual-

GENERALITAT VALENCIANA. $2002 \mathrm{~b}$. Importancia del cultivo de arroz en el Parc Natural de L'Albufera. Oficina de Gestión Técnica del Parc Natural de L'Albufera. Conselleria de Medio Ambiente. Valencia. España. Available: https://typsa.net/albufera/ 01 WEB_ED/01_AV_DSAV/04_GA/01 $M \bar{C} / 7$-Linkdocs/21121_Importancia $\% 2 \overline{0}$ arrozal\%20Albufera.pdf

GENERALITAT VALENCIANA. 2012. Memoria de Gestión. Parc Natural El Fondo. Dirección General de Medio Natural. Área de Gestión de Espacios Naturales Protegidos. Valencia. España. Available: http://www. parquesnaturales.gva.es/documents/ 80283153/163615883/MG_+2012_2.0_web. pdf/849c1 ea6-4e70-4822-859a-48b5fobeba37

GENERALITAT VALENCIANA. 2013. Aves acuáticas nidificantes en las zonas húmedas de la Comunidad Valenciana: 30 años de censos ininterrumpidos (1984-2013). (Informe Técnico 10/2013). Servicio de Vida Silvestre. Direcció General de Medi Natural. Consellería d' Infraestructures, Territori i Medi Ambient. Valencia. España. Available: http://www. agroambient.gva.es/documents/91061501/ $109950963 /$ Aves + acu $\%$ C $3 \%$ A 1 ticas + nidificantes + en+las + zonas $+\mathrm{h} \% \mathrm{C} 3 \% \mathrm{BAmedas}+$ $\mathrm{de}+\mathrm{la}+$ Comunitat + Valenciana/968d20e05d3b-4562-b2fa-d288f5897e22

GENERALITAT VALENCIANA. 2015. Censos de Aves Acuáticas Nidificantes en las Zonas Húmedas de la Comunitat Valenciana. Año 2015. (Informe Técnico 10/2015). Servici de Vida Silvestre. Direcció General de Medi Natural i d'Avaluació Ambiental. Consellería D'agricultura, Medi Ambient, Canvi Climàtic I Desenvolupament Rural. Valencia. España. Available: http://www.agroambient.gva.es/ documents/91061501/161573226/IT10 $2015+$ Censos + aves + acuaticas + nidificantes ${ }^{-}$ en+zonas+humedas+2015/f10ca984-7cdc4adc-a6d0-1bbd8bf72d76 
GENERALITAT VALENCIANA. 2016. Censos de Aves Acuáticas Nidificantes en las Zonas Húmedas de la Comunitat Valenciana. Año 2016. (Informe Técnico 13/2016). Servici de Vida Silvestre. Direcció General de Medi Natural i d'Avaluació Ambiental. Consellería D'agricultura, Medi Ambient, Canvi Climàtic I Desenvolupament Rural. Valencia. España. Available: http://www.agroambient.gva.es/ documents/91061501/162536532/IT 13 $2016+$ Censos+aves+acuaticas+nidificantes+ en + zonas + humedas $+2016 / 7320$ bd 11 d05e-488e-9185-75994dd73a8a

GENERALITAT VALENCIANA. 2018. Censos de Aves Acuáticas Nidificantes en las Zonas Húmedas de la Comunitat Valenciana. Año 2018. (Informe Técnico 07/2018). Servei de Vida Silvestre. Direcció General de Medi Natural i d'Avaluació Ambiental. Consellería D'agricultura, Medi Ambient, Canvi Climàtic I Desenvolupament Rural. Valencia. España. Available: http://www.agroambient.gva.es /documents/91061501/165536127/IT07 $2018+$ Censos + aves + acu $\%$ C3\%A 1 ticas + nidificantes $+2018 / \mathrm{d} 5453903-\mathrm{b} 6 \mathrm{f} 7-4 \mathrm{ceb}-$ 9ee3-ec5864ce7801

GÓMEZ LÓPEZ, J. A., J. I. DIES JAMBRINO \& M. VILALTA VILANOVA. (eds.) 2006. Las aves acuáticas de la Comunitat Valenciana, censos y evolución de las poblaciones (19842004). Conselleria de Territori i Habitatge, Generalitat Valenciana. Valencia. España.

GREEN, A. J. \& J. FIGUEROLA. 2003. Aves acuáticas como bioindicadores en los humedales. In: Ecología, manejo y conservación de humedales (Paracuellos, ed.): 47-60 Colección Actas, 49. Instituto de Estudios Almerienses (Diputación de Almería). Almería. España.

HAFNER, H., P. DUGAN \& V. BOY. 1987. Herons and Wetlands in the Mediterranean: development of indices for assessment and management of Mediterranean wetland ecosystems. Final Report $3^{\circ}$ Enviroment Research Programe. Comision of the European Comunities. IUCN.

HAFNER, H., O. PINEAU \& Y. KAYSER. 1994. Ecological determinants of annual fluctuations in numbers of breeding Little
Egrets (Egretta garzetta L.) in the Camargue, S. France. Revue D Ecologie-La Terre et la Vie, 49: 53-62.

HAMMER, $\varnothing$, D. A.T HARPER \& P. D. RYAN. 2001. PAST: Paleontological Statistic software package for education and data analysis. Palaeontologia Electronica, 4: 9pp

HATFIELD, J. S., W. R. GOULD, B. A. HOOVER, M. R. FULLER \& E. L. LINDQUIST.1996. Detecting trends in raptor counts: power and type I error rates of various statistical tests. Wildlife Society Bulletin, 24: 505-515.

IBAÑEZ, C., A. CURCO, X. RIERA, I. RIPOLL \& C. SÁNCHEZ. 2010. Influence on birds of rice field management practices during the growing season: a review and an experiment. Waterbirds, 33(sp1): 167-180. DOI: 10.1675/ 063.033.s 113

LEKUONA, J. 2002. Factores que influyen en la evolución temporal de la población reproductora de garza imperial, Ardea purpurea, en Navarra (Norte de España). Ecología, 16: 317-323.

MADROÑO, A., C. GONZÁlEZ \& J. C. ATIENZA (eds). 2004. Libro Rojo de las Aves de España. Dirección General para la Biodiversidad-SEO/BirdLife. Madrid.

MANIKOWSKA-ŚLEPOWROŃSKA， B., K. ŚLEPOWROŃSKI \& D. JAKUBAS. 2016. Grey Heron Ardea cinerea productivity in relation to habitat features and different spatial scales. Polish Journal of Ecology, 64: 384-398. DOI: 10.3161/15052249PJE2016. 64.3.008

MARTÍNEZ-ABRAIN, A., J. JIMENEZ, J.A. GOMEZ \& D. ORO. 2016. Differential waterbird population dynamics after long-term protection: the influence of diet and habitat type. Ardeola, 63: 79-101. DOI: 10.13157/ arla.63.1.2016.rp4

MEDWET-THE MEDITERRANEAN WETLANDS INICIATIVE. 2016. Wetlands for Sustainable Development in the Mediterranean Region: A Framework for Action 20162030. 12th Meeting of the Mediterranean Wetlands Committee (MedWet/Com). Paris, Francia.

MILLENNIUM ECOSYSTEM ASSESSMENT. 
2005. Ecosystems and human well-being: wetlands and water. Synthesis. World Resources Institute, Washington, DC.

PALOMINO, D. \& B. MOLINA. (eds.) 2009. Aves acuáticas reproductoras en España. Población en 2007 y método de censo. SEO/BirdLife. Madrid.

PAREJO, D., J. M. SÁNCHEZ-GUZMÁN \& J.M. AVILÉS. 2001. Breeding biology of the Cattle Egret Bubulcus ibis in southwest Spain. Bird Study, 48:3, 367-372, DOI: 10.1080/ 00063650109461236

PECHUAN, L. 1971. Sobre la colonia de garzas del Lago de La Albufera de Valencia. Ardeola, Vol. esp: 397-404.

PÉREZ-ARANDA, D., F. IBAÑEZ, L. GARCÍA, M. GIMÉNEZ, H. GARRIDO \& M. MAÑEZ. 2003. Garcilla cangrejera, Ardeola ralloides. In: Atlas de las aves reproductoras de España. R. Marti y J. C. Del Moral (eds.): 124-125. Dirección General de Conservación de la Naturaleza. Sociedad Española de Ornitología. Madrid. España.

PICAZO-TADEO, A. J., E. REIG-MARTÍNEZ \& V. ESTRUCH. 2009. Farming efficiency and the survival of valuable agro-ecosystems: a case study of rice farming in European Mediterranean wetlands. Open Environmental Sciences, 3: 42-51. DOI:10.2174/ 1876325100903010042

PROSPER, J. 2000. Las ardeidas coloniales en l'Albufera de Valencia. Biología de tres especies: Garcilla Bueyera (Bubulcus ibis), Garceta Común (Egretta garzetta) y Garza Real (Ardea cinerea). Ph. D. Thesis. Universitat de Valencia. España.

PROSPER, J. \& H. HAFNER. 1996. Breeding aspects of the colonial Ardeidae in the Albufera de Valencia, Spain: population changes, phenology, and reproductive success of the three most abundant species. Colonial Waterbirds, Vol. 19 (sp1): Ecology, Conservation, and Management of Colonial Waterbirds in the Mediterranean Region. pp. 98-107.

RAMO, C., E. AGUILERA, J. FIGUEROLA, M. MÁÑEZ \& A. J. GREEN. 2013. Long-term population trends of colonial wading birds breeding in Doñana (SW Spain) in relation to environmental and anthropogenic factors. Ardeola, 60:305-326. DOI: 10.13157/arla.60. 2.2013.305

REAL DECRETO 139/2011, de 4 de febrero, para el desarrollo del Listado de Especies Silvestres en Régimen de Protección Especial y del Catálogo Español de Especies Amenazadas. Available: https://www.boe.es/buscar/ doc.php?id=BOE-A-2011-3582

RED NATURA 2000. http://www.agroambient. gva.es/es/web/red-natura-2000/espaciosred-natura-2000. Consulted: 28/03/2018

SÁNCHEZ-GUZMÁN, J. M., R. MORÁN, J. A. MASERO, C. CORBACHO, E. COSTILLO, A. VILLEGAS, \& F. SANTIAGO-QUESADA. 2007. Identifying new buffer areas for conserving waterbirds in the Mediterranean basin: the importance of the ricefields in Extremadura, Spain. Biodiversity and Conservation, 16: 3333-3344. DOI: 10.1007/978-14020-6865-2 7

SANTORO, S., M. MAÑEZ, A. J. GREEN. \& J. FIGUEROLA. 2010. Formation and growth of a heronry in a managed wetland in Doñana, southwest Spain. Bird Study, 57: 515-524. DOI: 10.1007/978-1-4020-6865-2 7

SANTORO, S., GREEN, A. J., \& J. FIGUEROLA. 2013. Environmental instability as a motor for dispersal: a case study from a growing population of glossy ibis. PloS one, 8(12), e82983.

SANTORO, S., GREEN, A. J., \& J. FIGUEROLA. 2016. Immigration enhances fast growth of a newly established source population. Ecology, 97: 1048-1057.

TORAL, G. M., R. A. STILLMEN, S. SANTORO \& J. FIGUEROLA. 2012. The importance of rice fields for Glossy Ibis (Plegadis falcinellus): management recomendations derived from an individual-based model. Biological Conservation, 148: 19-27. DOI: 10.1016/j.biocon.2012.02.001

TOURENQ, C., R. E. BENNETTS, N. SADOUL, F. MESLEARD, Y. KAYSER \& H. HAFNER. 2000. Long-term population and colony patterns of four species of tree nesting herons in the Camargue, South France. Waterbirds, 23: 236-245. 